\title{
Effect of Mirabegron on Intraocular Pressure in Patients with Glaucoma
}

\section{Glokomlu Hastalarda Mirabegronun Göz Içi Basıncı Üzerine Etkisi}

\author{
D Emine Şeker Ün1, 囵Sıtkı Ün² \\ 1 Pamukkale University Faculty of Medicine, Department of Ophthalmology, Denizli, Turkiye \\ 2 Pamukkale University Faculty of Medicine, Department of Urology, Denizli, Turkiye
}

What's known on the subject? and What does the study add?

Safety of using mirabegron in glaucoma patients.

\begin{abstract}
Objective: Assessment of the effects of mirabegron treatment used for overactive bladder (OAB) symptoms in glaucoma patients on intraocular structures.

Materials and Methods: One hundred-twenty six female glaucoma patients, who received mirabegron treatment for OAB symptoms between January 2017 and January 2018, were included in the study. One hundred-twenty female glaucoma patients were chosen as controls. The mean age of the patients in the study and control groups was 46.74 and 44.42 , respectively. A daily single dose of 50 mg mirabegron was prescribed for $0 A B$ treatment. Intraocular pressure (IOP) was assessed in $4^{\text {th }}$ and $12^{\text {th }}$ weeks in both groups. In the beginning of the treatment period, the mean IOP was $15.20( \pm 3.20) \mathrm{mmHg}$ in the study group and $15.70( \pm 4.20) \mathrm{mmHg}$ in controls.

Results: The mean IOP in the study group was $15.80( \pm 3.80) \mathrm{mmHg}$ and $16( \pm 4.20) \mathrm{mmHg}$ on the $4^{\text {th }}$ and $12^{\text {th }}$ weeks, respectively. The mean IOP controls was $15.60( \pm 4.80)$ and $15.80( \pm 3.20) \mathrm{mmHg}$ on the $4^{\text {th }}$ and $12^{\text {th }}$ weeks, respectively. No significant difference was found on the $4^{\text {th }}$ and $12^{\text {th }}$ weeks of treatment between the groups in terms of intraocular pressure.
\end{abstract}

Conclusion: Mirabegron treatment used for OAB does not affect IOP in patients treated for primary open-angle glaucoma.

Keywords: Mirabegron, Glaucoma, Overactive bladder

öz

Amaç: Glokom tedavisi almakta olan hastalarda aşırı aktif mesane semptomları nedeniyle kullanılan mirabegron tedavisinin göz içi üzerine etkilerini araştırmaktır.

Gereç ve Yöntem: Ocak 2017-Ocak 2018 tarihleri arasında glokom tedavisi almakta iken aşırı aktif mesane semptomları nedeniyle mirabegron tedavisi planlanan 126 kadın hasta çalışmaya alındı. Kontrol grubunda yine glokom tedavisi alan 120 kadın hasta çalışmaya alındı. Yaş ortalaması çalışma grubunda 46,74, kontrol grubunda 44,42 idi. Aşırı aktif mesane tedavisi için 50 mg günde tek doz mirabegron verildi. Her iki grupta 4 . ve 12. haftalarda göz içi basınçları değerlendirildi. Tedavi başlangıında çalışma grubunda göz içi basıncı ortalaması $15,20( \pm 3,20) \mathrm{mmHg}, \mathrm{kontrol}$ grubunda ise $15,70( \pm 4,20) \mathrm{mmHg}$ idi.

Bulgular: Çalışma grubunda sırasıyla 4. ve 12. hafta göz içi basınç ortalaması $15,80( \pm 3,80) \mathrm{mmHg}, 16,00( \pm 4,20) \mathrm{mmHg}$ idi. Kontrol grubunda ise $15,60( \pm 4,80) \mathrm{mmHg}, 15,80( \pm 3,20) \mathrm{mmHg}$ idi. İki grup arasında göz içi basınçları arasında 4. ve 12. haftalarda istatistiksel olarak anlamlı farklılık saptanmadı.

Sonuç: Primer açık açılı glokom tedavisi alan hastalarda aşırı aktif mesane nedeniyle kullanılan mirabegron tedavisi göz içi basıncına etki etmemektedir.

Anahtar Kelimeler: Mirabegron, Glokom, Aşırı aktif nesne

Correspondence: Sıtkı Ün MD, Pamukkale University Faculty of Medicine, Department of Urology, Denizli, Turkiye

Phone: +90 553-6557820 E-mail: sitki@doctor.com ORCID-ID: orcid.org/0000-0003-1477-7497

Received: 25.11.2019 Accepted: 25.11.2019

Cite this article as: Ün EŞ, Ün S. Effect of Mirabegron on Intraocular Pressure in Patients with Glaucoma. Journal of Urological Surgery, 2020;7(2):134-138.

${ }^{\circ}$ Copyright 2020 by the Association of Urological Surgery / Journal of Urological Surgery published by Galenos Publishing House. 


\section{Introduction}

In this study, our main objective was to study the effect of mirabegron treatment used for overactive bladder (OAB) symptoms on intraocular pressure (IOP) in primary open-angle glaucoma (POAG) patients.

Glaucoma is defined as the optic neuropathies, characterized by structural changes in the optic nerve head. Those neuropathies can cause reduction in visual field and ultimately, blindness (1). The most common types of glaucoma are POAG and primary closed-angle glaucoma (PCAG), with the incidence rate of POAG about 7 times higher than PCAG in the USA and Europe (1).

$O A B$ is a frequently seen disorder which severely affects the patients' quality of life in a negative way. $O A B$ can be seen on its own as urgency incontinence or with accompanying urinary incontinence, nocturia and increased urinary frequency (2). The overall prevalence of $O A B$ symptoms has been reported to be $16 \%$ (3). Muscarinic acetylcholine receptor antagonists (antimuscarinics) are the first-line treatment for $O A B$ after life style modifications. Their therapeutic effect is on M2 and M3 muscarinic receptors in the bladder, preventing abnormal detrusor actions caused by acetylcholine in $\mathrm{OAB}(4,5)$.

Although most of the medications used in treatment are known to have anticholinergic effects, there is still no clear consensus on the safety and reliability of those medications in glaucoma treatment $(6,7)$. Moreover, muscarinic receptors are also present in the eye, adjusting the autonomic response of the iris sphincter by controlling the constriction response (8).

For this reason, M3 muscarine antagonists, such as atropine, are not recommended in uncontrolled narrow-angle glaucoma patients for treatment due to their effects of causing mydriasis, blurred vision and narrowing of the anterior chamber (9). Mirabegron, however, does not directly affect muscarinic receptors like antimuscarinics influencing bladder emptying contractions. Instead, they simulate B3-adrenoceptors found in detrusor muscles which facilitate filling and storage of the bladder (10). High tolerability of daily single-dose mirabegron has been reported with positive effects in urinary incontinence and miction related with $\mathrm{OAB}$ symptoms. The incidence of sideeffect in patients receiving mirabegron treatment has been reported to be similar to that in placebo groups $(11,12,13)$.

In an in vitro study using bovine samples reported that the beta-adrenergic relaxation response in the iris sphincter muscle was controlled by beta-adrenergic receptor family, with a predominant contribution of atypical, possibly B3 subtype, receptors (14). It has been reported that B3-adrenoceptors were detected in conjunctival epithelial cells in rat conjunctivital samples, which is thought to play a role in retinal vascular tonus control in rats and was also seen in both choroidal and retinal endothelium $(15,16,17)$.
In this study, we assessed the effects of mirabegron on IOP in glaucoma patients with $O A B$ syndrome. Previous studies on this subject were done using patients without glaucoma but ours is the first which included glaucoma patients.

\section{Materials and Methods}

The main objective of this study was to assess the ocular safety of mirabegron in glaucoma patients under a controlled clinical environment. This assessment was done by evaluating the effects of daily $50 \mathrm{mg}$ mirabegron on IOP in POAG patients and comparing that with a control group.

This retrospective study was done as a joint study with ophthalmology and urology departments between January 2017 and January 2018. The study included female POAG patients who were treated with a daily dose of $50 \mathrm{mg}$ mirabegron for $\mathrm{OAB}$ symptoms. Patients with previous eye surgery, uncontrolled glaucoma and narrowed anterior chamber angle were excluded. Moreover, patients with a systemic disease, previous incontinence surgery, urinary retention and bowel obstruction, as well as pregnant and nursing female patients were also excluded.

All patients underwent a complete ophthalmologic examination including vision acuity measurement using Snellen charts, IOP measurement using Goldmann applanation tonometer, biomicroscopic evaluation, gonioscopy and fundus examination. $O A B$ patients were asked to keep a 3-day voiding diary recording their daily voiding frequency and episodes of nocturia and urgency incontinence. Mirabegron was started as a single daily dose of $50 \mathrm{mg}$ and follow-up evaluation was done on the $4^{\text {th }}$ week. Daily voiding frequency, and episodes of nocturia and urgency incontinence were taken from patients' voiding diaries on the $4^{\text {th }}$ week of treatment and side effects, if any, were recorded. The patients then underwent another complete ophthalmologic examination and IOP measurement.

The treatment and follow-up were done by an ophthalmologist. The treatment was continued in patients who reported improvement and no side effects. All the procedures done on the $4^{\text {th }}$ week were repeated on the $12^{\text {th }}$ week. The results were assessed in terms of drug efficiency, side effects and IOP.

\section{Statistical Analysis}

Statistical analysis was done using the SPSS 11.5.0 for Windows (SPSS, Chicago, IL, USA). Normal distribution of each variable was analyzed using the Kolmogorov-Smirnov and ShapiroWilk tests. The Mann-Whitney U test was used to compare two independent groups with non-normal distribution. Categorical variables were assessed using Pearson's chi-square test. Descriptive statistics were expressed as frequency and percentages in categorical variables and as mean and standard 
deviation in quantitative variables with normal ditribution and as median (minimum-maximum) in variables without normal distribution. Statistical significance level was set as $p<0.05$.

\section{Results}

One hundred-twenty six POAG patients with OAB symptoms were included in the study. The treatment was stopped due to side-effects in 2 patients. Another 2 patients, who reported subjective symptoms such as blurred vision, dry eyes, stinging eyes and foreign body sensation and were treated by the ophthalmologist for those complaints, were excluded from the study. One patient developed urinary tract infection and 1 , upper respiratory tract infection and were both treated with antibiotics.

One hundred-twenty POAG patients were included in the study as controls. Forty six patients in the study group received monotherapy and 78 received a combination therapy for glaucoma whereas 50 patients received monotherapy and 70 received a combination glaucoma therapy in control group. The antiglaucoma drugs used in both groups were similar. Daily voiding frequency, nocturia and urgency incontinence showed a significant improvement from the baseline to the $4^{\text {th }}$ and $12^{\text {th }}$ weeks (Table 1).

Systemic side effect rates were reported to be similar on week 4 and week 12. The mean age of the 124 patients was $46.74 \pm 7.2$ years (41-72). The mean age of the 120 female patients in control group was $44.42 \pm 6.6$ years (39-69) (Table 2 ).

Table 3 shows IOP measurements. The median IOP value in the study group was $15.20( \pm 3.20) \mathrm{mmHg}$ prior to treatment (baseline), $15.80( \pm 3.80) \mathrm{mmHg}$ on week 4 and $16.00( \pm 4.20)$ $\mathrm{mmHg}$ on week 12. No significant difference was seen between baseline, week 4 and week 12 measurements $(p=0.258$ and

Table 1. Over active bladder symptoms

\begin{tabular}{|l|l|l|l|l|}
\hline & Baseline & Week 4 & Week 12 & $\mathbf{p}$ \\
\hline Daily voiding frequency & 10.8 & 6.8 & 5.4 & 0.037 \\
\hline Nocturia & 4.2 & 3.0 & 2.6 & 0.022 \\
\hline Urgency incontinence & 3.4 & 1.8 & 0.8 & 0.045 \\
\hline
\end{tabular}

Table 2. Pretreatment findings

\begin{tabular}{|l|l|l|l|}
\hline & Control Group & Study Group & $\mathbf{p}$ \\
\hline Mean Age \pm SD & $44.42 \pm 6.6$ years & $46.74 \pm 7.2$ years & 0.168 \\
\hline Mean IOP & $\begin{array}{l}15.70( \pm 4.20) \\
\mathrm{mmHg}\end{array}$ & $\begin{array}{l}15.20( \pm 3.20) \\
\mathrm{mmHg}\end{array}$ & 0.352 \\
\hline Monotherapy & 50 & 46 & 0.744 \\
\hline $\begin{array}{l}\text { Combination } \\
\text { therapy }\end{array}$ & 70 & 78 & 0.698 \\
\hline \multicolumn{2}{|l|}{ SD: Standard deviation, IOP: Intraocular pressure } \\
\hline
\end{tabular}

$p=0.176$, respectively). The median IOP value in control group was $15.70( \pm 4.20) \mathrm{mmHg}$ prior to study (baseline), $15.60( \pm 4.80)$ $\mathrm{mmHg}$ on week 4 and $15.80( \pm 3.20) \mathrm{mmHg}$ on week 12. Similarly, no significant difference was seen between baseline, week 4 and week 12 measurements ( $p=0.048$ and $p=0.244$, respectively) (Table 3).

Difference in visual acuity and biomicroscopic findings were found to be transient on the $4^{\text {th }}$ and $12^{\text {th }}$ weeks with limited clinical significance and in similar rates between the groups. None of the patients required a treatment change or experienced a situation requiring additional treatment (Table 4).

\section{Discussion}

$O A B$ is defined as urinary urgency, usually with urinary frequency and nocturia, with or without urgency urinary incontinence (4). Mirabegron is a potent and selective B3-adrenoceptor agonist; making it the first medication in a new class of drugs used in the medical treatment of OAB (11).

Although $O A B$ and glaucoma are frequent, the prevalence of those diseases is higher in elderly patients both as single and combined entities $(18,19)$. Mirabegron is a B3-adrenoceptor agonist used commonly in $\mathrm{OAB}$ patients with possible systemic side effects. Still, mirabegron is an effective medication used for improving $\mathrm{OAB}$ symptoms. In our study, we assessed also the improvement of OAB symptoms in the patients (20). The study compared glaucoma patients, who received mirabegron $50 \mathrm{mg}$ treatment, with controls. Patients, in whom the medication was

Table 3. Comparison of intraocular pressure measurements

\begin{tabular}{|l|l|l|l|}
\hline & \multicolumn{2}{|l|}{ Mean } & p \\
\hline $\begin{array}{l}\text { Study group } \\
\text { (0-4 weeks) }\end{array}$ & $15.20( \pm 3.20) \mathrm{mmHg}$ & $15.80( \pm 3.80) \mathrm{mmHg}$ & 0.258 \\
\hline $\begin{array}{l}\text { Study group } \\
\mathbf{( 0 - 1 2} \text { weeks) }\end{array}$ & $15.20( \pm 3.20) \mathrm{mmHg}$ & $16.00( \pm 4.20) \mathrm{mmHg}$ & 0.176 \\
\hline $\begin{array}{l}\text { Controls } \\
\mathbf{( 0 - 4} \text { weeks) }\end{array}$ & $15.70( \pm 4.20) \mathrm{mmHg}$ & $15.60( \pm 4.80) \mathrm{mmHg}$ & 0.448 \\
\hline $\begin{array}{l}\text { Controls } \\
\mathbf{( 0 - 1 2} \text { weeks) }\end{array}$ & $15.70( \pm 4.20) \mathrm{mmHg}$ & $15.80( \pm 3.20) \mathrm{mmHg}$ & 0.244 \\
\hline
\end{tabular}

Table 4. Side effects

\begin{tabular}{|l|l|l|}
\hline & $\begin{array}{l}\text { Study group } \\
(\mathbf{n}=120)\end{array}$ & $\begin{array}{l}\text { Control group } \\
(\mathbf{n}=124)\end{array}$ \\
\hline $\begin{array}{l}\text { Conjunctiva irritation and } \\
\text { inflammation }\end{array}$ & 0 & 1 \\
\hline $\begin{array}{l}\text { Iris and uveal channel irritation and } \\
\text { inflammation }\end{array}$ & 0 & 1 \\
\hline Dry eye & 0 & 1 \\
\hline Painful eye & 1 & 0 \\
\hline Foreign body sensation in eye & 1 & 0 \\
\hline Decreased visual acuity & 0 & 1 \\
\hline
\end{tabular}


effective with minimum side effects, continued treatment. All the procedures performed on week 4 were repeated on week 12 and the results were reviewed in terms of drug efficiency, side effects and IOP.

This study where we assessed the ocular safety of mirabegron reported that a daily dose of $50 \mathrm{mg}$ mirabegron did not affect IOC, in patients of treatment group when compared with controls. IOP was also found to be similar in patients who received monotherapy or combined therapy for glaucoma. The difference between IOP on week 4 and week 12 in glaucoma patient population stayed on a low level and other ocular safety factors were not assessed. Moreover, this study showed a significant improvement in voiding frequency, nocturia and urgency incontinence in treatment group when compared to controls.

Previous studies showed similar ocular side effects in patients receiving mirabegron and placebo (11-20), which is similar to our study with transient and similar rate of side effects in both groups. Previous mirabegron studies reported that the most common systemic side effects were hypertension (7.3\%), nasopharyngitis (3.4\%) and urinary tract infection (3\%) (21). In our study, 1 patient (0.79\%) developed urinary tract infection and 1 developed (0.79\%) upper respiratory tract infection. Mirabegron has also been shown not to increase IOP in healthy controls in randomized, double-blind placebo-controlled studies (20). Likewise in our study, we observed that mirabegron did not increase IOP in glaucoma patients, did not lead to requirement of additional treatments and can be used safely in patients with glaucoma.

In vitro studies on choroidal and retinal cells have shown that b3-agonists promoted cell proliferation and migration. It was beyond the scope of our study to evaluate the potential effects in patients with ocular angiogenic disorders, although this may be of interest. The clinical significance of those results is still unclear $(15,16,17)$.

Mirabegron $50 \mathrm{mg}$ daily for 12 weeks did not increase IOP values in glaucoma patients and was considered safe and well-tolerated. However, those results must be supported by prospective studies. In addition, as all the previous studies were done on patients with normal IOP, there were no studies to compare our results with. For this reason, our study is the first study on this subject to the best of our knowledge.

\section{Conclusion}

In conclusion, the fact that mirabegron did not negatively affect IOP, even in glaucoma patients, is a very important finding to show the safety of mirabegron in patients with and without glaucoma.

\section{Ethics}

Ethics Committee Approval: Retrospective study.

Informed Consent: Retrospective study.

Peer-review: Internally peer-reviewed.

\section{Authorship Contributions}

Concept: E.Ş.Ü., S.Ü., Design: E.Ş.Ü., S.Ü., Data Collection or Processing: E.Ş.Ü., S.Ü., Analysis or Interpretation: E.S..Ü., S.Ü., Literature Search: E.Ş.Ü., S.Ü., Writing: E.Ş.Ü., S.Ü.

Conflict of Interest: All authors declared that there was no any conflict of interest.

Financial Disclosure: The authors declare that they have no relevant financial.

\section{References}

1. Quigley HA, Broman AT. The number of people with glaucoma worldwide in 2010 and 2020. Br J Ophthalmol 2006;90:262-267.

2. Jain D, Dhua A, Ravisankar V, Chellam L, Joshi MJ. Acute angle closure glaucoma after hypospadias surgery: a vision-threatening complication of oxybutynin. J Indian Assoc Pediatr Surg 2015;20:161-162.

3. Milsom I, Abrams P, Cardozo L, Roberts RG, Thüroff J, Wein AJ. How widespread are the symptoms of an overactive bladder and how are they managed? A population-based prevalence study. BJU Int 2001;87:760-766.

4. Abrams $P$, Cardozo L, Fall $M$, Griffiths $D$, Rosier $P$, Ulmsten U, Van KP Victor $A$, and Wein A. The standardisation of terminology in lower urinary tract function: report from the standardisation sub-committee of the International Continence Society. Urology 2003;61:37-49.

5. Kato K, Yoshida K, Suzuki K, Murase T, Gotoh M. Managing patients with an overactive bladder and glaucoma: a questionnaire survey of Japanese urologists on the use of anticholinergics. BJU Int 2005;95:98-101.

6. Eskandar OS, Eckford SD, Whittaker KW. Treatment of overactive bladder $(\mathrm{OAB})$ with anti-cholinergic drugs and the risk of glaucoma. J Obstet Gynaecol 2005;25:419-421.

7. Abrams $P$, Andersson $K E$, Buccafusco JJ, Chapple $C$, de Groat WC, Fryer AD, Kay G, Laties A, Nathanson NM, Pasricha PJ, Wein AJ. Muscarinic receptors: their distribution and function in body systems, and the implications for treating overactive bladder. Br J Pharmacol 2006;148:565-578.

8. Mindel JS. Cholinergic Pharmacology. Duane's Ophthalmology. Philadelphia, PA: Lippincott, Willilams and Wilkins; 2006.

9. Bragg R, Hebel D, Vouri SM, Pitlick JM. Mirabegron: a Beta-3 agonist for overactive bladder. Consult Pharm 2014;29:823-837.

10. Chapple CR, Cardozo L, Nitti VW, Siddiqui E, Michel MC. Mirabegron in overactive bladder: a review of efficacy, safety, and tolerability. Neurourol Urody 2014;33:17-30.

11. Nitti VW, Auerbach S, Martin N, Calhoun A, Lee M, Herschorn S. Results of a randomized phase III trial of mirabegron in patients with overactive bladder. J Urol 2013;189:1388-1395.

12. Andersson $K E$, Choudhury $N$, Cornu JN, Huang M, Korstanje C, Siddiqui $E$, Van Kerrebroeck P. The efficacy of mirabegron in the treatment of urgency and the potential utility of combination therapy. Ther Adv Urol 2018;10:243-256.

13. Lee $\mathrm{CL}$, Kuo HC. Efficacy and safety of mirabegron, a $\beta 3$-adrenoceptor agonist, in patients with detrusor hyperactivity and impaired contractility. Low Urin Tract Symptoms 2019;11:093-097. 
14. Geyer O, Bar-llan A, Nachman R, Lazar M, Oron Y. Beta3-adrenergic relaxation of bovine iris sphincter. FEBS Lett 1998;429:356-358.

15. Diebold Y, Rios JD, Hodges RR, Rawe I, Dartt DA. Presence of nerves and their receptors in mouse and human conjunctival goblet cells. Invest Ophthalmol Vis Sci 2001;42:2270-2282.

16. Mori A, Nakahara T, Sakamoto K, Ishii K. Role of beta3-adrenoceptors in regulation of retinal vascular tone in rats. Naunyn Schmiedebergs Arch Pharmacol 2001;384:603-608.

17. Steinle JJ, Zamora DO, Rosenbaum JT, Granger HJ. Beta 3-adrenergic receptors mediate choroidal endothelial cell invasion, proliferation, and cell elongation. Exp Eye Res 2005;80:83-91.

18. Yamaguchi O, Nishizawa O, Takeda M, Yokoyama O, Homma Y, Kakizaki H, Obara K, Gotoh M, Igawa Y, Seki N, Yoshida M, Neurogenic Bladder Society. Clinical guidelines for overactive bladder. Int J Urol 2009;16:126-142.
19. Iwase A, Suzuki $Y$, Araie M, Yamamoto T, Abe H, Shirato S, Kuwayama $Y$, Mishima HK, Shimizu H, Tomita G, Inoue Y, Kitazawa Y, Tajimi Study Group. The prevalence of primary open-angle glaucoma in Japanese: the Tajimi Study. Ophthalmology 2004;111:1641-1648.

20. Novack GD, Lewis RA, Vogel R, Sheth $N$, Swearingen D, Rasmussen $S$, Hantsbarger G, Martin NE. Randomized, double-masked, placebo-controlled study to assess the ocular safety of mirabegron in healthy volunteers. J Ocul Pharmacol Ther 2013;29:674-680.

21. Chapple CR1, Cardozo L, Nitti VW, Siddiqui E, Michel MC. Mirabegron in overactive bladder: a review of efficacy, safety, and tolerability. Neurourol Urodyn 2014;3:17-30. 